\title{
Examination of the Level of Adequacy of Sports Facilities in Terms of Popularization of Sports in Bingöl
}

\author{
Ömer ÇELIK ${ }^{1}$, Süreyya Yonca SEZER ${ }^{2}$, Mustafa KARADAĞ ${ }^{2}$, Yüksel SAVUCU ${ }^{2}$, Mikail TEL ${ }^{2} \&$ Baha Engin \\ ÇELIKEL ${ }^{2}$ \\ ${ }^{1}$ The provincial directorate of youth services and sports, Bingöl, Turkey \\ ${ }^{2}$ Faculty of Sports Sciences, Firat University, Elazı ğ, Turkey \\ Correspondence: Yüksel Savucu, Faculty of Sports Sciences, Frrat University, Elazı̆̆, Turkey. Tel: \\ 90-0-424-237-0000-4467. E-mail: ysavucu@hotmail.com
}

Received: March 10, 2017

Accepted: April 23, 2017

Online Published: August 27, 2017

doi:10.5539/ies.v10n9p54

URL: https://doi.org/10.5539/ies.v10n9p54

\begin{abstract}
In this study, the level of adequacy of sports facilities in Bingöl province in terms of popularization of sports in the city and the general tendency of the citizens of Bingöl province towards sports were examined. A total of 610 volunteers from various professions, age groups and gender groups from Bingöl city center participated in this study. Questionnaires were applied to the subjects who participated. There are 31 questions in the questionnaire. The sample group of tradesmen and their customers in Bingöl province were contacted by random sampling method. Survey questions were asked face to face for the purpose of getting the necessary data for the goal of the research. In the evaluation of the obtained data, the frequency and percentage distributions were calculated and tested by applying the Chi-square test to see if there are any relationships between the variables. In the light of this research, it is observed that a large majority of people living in Bingöl are interested in sports, and football is the first among all sports branches of interest. The most important factor preventing sports being more widespread was found to be the lack of adequate sports facilities in the city, and it was also observed that public institutions and organizations lack their own sports facilities. For sports programs and facilities to be newly constructed, the public's interest and expectations should be taken into account. It has also been understood that in order to popularize mass sports events in Bingöl, the number of sports facilities and sports clubs should be increased too.
\end{abstract}

Keywords: sports facilities, capacity, sports programs, sports activities

\section{Introduction}

With the population increase and development of sports activities in Bingöl province, the need for more sports facilities is increasing day by day. For this reason, it is necessary to establish a scientific approach for the planning phase of sports facilities before they are even started to be constructed.

Because Bingöl province is located at the crossroads of Eastern Anatolia's transportation network, it is necessary for its sports facilities to be able to host a variety of sports organizations.

The diversity of the existing sports facilities in the city and the differences arising from the way that different types of sports are performed are the main reasons for complicating the planning of such facilities.

The Ministry of Youth and Sports attach considerable importance to the investment of sports facilities in recent years. However, it is obvious that the facilities already constructed or to be constructed are planned without any consideration in regional differences.

In Bingöl province, the management responsibility of sports facilities also officially belongs to The General Directorate of Sports, since they also deal with investments in the area. It is necessary for the sports facilities managed by Youth Services and Sports Provincial Directorate and the ones managed by the Provincial National Education Directorate, and as well as the facilities owned by the Private Businesses in Bingöl are operated efficiently, and are available for the use of athletes and the public at all times.

\subsection{Basic Factors in Popularizing Sports}

It is possible to rapidly popularize, develop sports and to discipline and govern the sports environment in terms 
of quality and quantity, with the establishment of an independent sports management system with a good character, which consist of elements necessary for the existence and continuity of the sports activities (Devecioğlu, 1996).

Another factor in the popularization of sports is the data that will be obtained in the feasibility study of the sports facilities beforehand. These data can be used for short, medium and long term planning of sports facilities to increase the capacity and service for the popularization of sports. Another factor is the contribution of the people to the formation of a sports culture by establishing a qualified sports marketing and advertisement effort.

\subsection{Sports Facilities in Popularization of Sports}

One of the structures that form the basis of sports is sports facilities themselves. The capacity of sports facilities and services play an important role in the provision of the sports services to the public in the best way possible. For the popularization of sports, the determination of the capacity of sports facilities needs to be done within the framework of certain scientific studies. Sports facilities that are vital for the popularization of sports need to be addressed in a specific policy context (both in the construction phase and in the operation phase). Therefore, in order for a policy to be effective in this issue, the society's needs and expectations regarding sports and the education level and preferences should be investigated first (Ayan, 2002). In this context, in our research, it has been considered as an important issue to examine the adequacy of sports facilities in the popularization of sports in Bingöl. It is also important to determine the appropriate facilitation policies for increasing the diversity of sports branches so that the levels of participation in the sports are transformed from passive monitoring to active participation according to the sports branches people are interested in.

\section{Materials and Methods}

The universe of the research consists of individuals living in Bingöl city center in the Eastern Anatolia Region. The sample of the study consists of a total 610 people, 457 male and 153 female, living in Bingöl city center who are students, pensioners, farmers, workers, housewives, self-employed, civil servants and tradesmen.

Survey model was used in the study. A questionnaire developed by Ayan (2002) and used for the post graduate study called "the study of the sports facilities and sports policies applied for the popularization of sports in Kırıkkale" was used in this research in order to determine the views of the sample group. The survey form used in the research consists of two parts. In the first part, there are questions about demographic information. In the second part, there are a total of 31 questions regarding the level of adequacy of sport facilities in the popularization of sports in Bingöl and the study of the tendency of people to participate in sports activities. The sample group consisting of shopkeepers and their customers in the city center of Bingöl was collected by random sampling method. Survey questions were applied face to face for the purpose of the research.

SPSS 15.0 package program was used for analyzing the data obtained. Arithmetic mean, percent (\%) and frequency (f) were used in the data analysis obtained from the research. Whether or not the difference between participants' gender, age, marital status and educational status and their interest in the sports was significant, was determined by applying the $\mathrm{X} 2$ test.

\section{Findings}

In Table 1, the interest ratio of male participants towards sports was found to be $68.9 \%$ while the same ratio in females was $64.7 \%$. The level of interest in sports for female participants is lower than that of males. This difference observed in the interest level towards sports of male and female participants was found to be insignificant.

Table 1. Gender difference and the level of interest towards sports

\begin{tabular}{ccccccc}
\hline Gender & \multicolumn{3}{c}{ Interest towards Sports } & \multicolumn{2}{c}{ Total } \\
\cline { 2 - 5 } & \multicolumn{2}{c}{ Yes } & \multicolumn{2}{c}{ No } & & \\
\cline { 2 - 5 } & $\mathrm{N}$ & $\%$ & $\mathrm{~N}$ & $\%$ & $\mathrm{~N}$ & $\%$ \\
\hline Male & 315 & 68.9 & 142 & 31.1 & 457 & 100 \\
Female & 99 & 64.7 & 54 & 35.3 & 153 & 100 \\
\hline
\end{tabular}


Table 2. Age difference and the level of interest towards sports

\begin{tabular}{|c|c|c|c|c|c|c|}
\hline \multirow[t]{3}{*}{ Age } & \multicolumn{4}{|c|}{ Interest towards Sports } & \multicolumn{2}{|c|}{ Total } \\
\hline & \multicolumn{2}{|c|}{ Yes } & \multicolumn{2}{|c|}{ No } & \multirow[b]{2}{*}{$\mathbf{N}$} & \multirow[b]{2}{*}{$\%$} \\
\hline & $\mathbf{N}$ & $\%$ & $\mathbf{N}$ & $\%$ & & \\
\hline 17 and younger & 60 & 75.0 & 20 & 25.0 & 80 & 100 \\
\hline $18-25$ & 130 & 77.8 & 37 & 22.2 & 167 & 100 \\
\hline $26-35$ & 103 & 75.7 & 33 & 24.3 & 136 & 100 \\
\hline $36-45$ & 74 & 62.1 & 45 & 37.9 & 119 & 100 \\
\hline $46-65$ & 49 & 52.6 & 44 & 47.4 & 93 & 100 \\
\hline 66 and older & 5 & 33.3 & 10 & 66.7 & 15 & 100 \\
\hline
\end{tabular}

Table 3. The difference in marital status and the level of interest towards sports

\begin{tabular}{ccccccc}
\hline Marital Status & \multicolumn{3}{c}{ Interest towards Sports } & \multicolumn{2}{c}{ Total } \\
\cline { 2 - 5 } & \multicolumn{2}{c}{ Yes } & \multicolumn{2}{c}{ No } & & \\
& $\mathbf{N}$ & $\mathbf{\%}$ & $\mathbf{N}$ & $\mathbf{\%}$ & $\mathbf{N}$ & $\mathbf{\%}$ \\
\hline Single & 277 & 77.8 & 79 & 22.2 & 356 & 100 \\
Married & 149 & 58.6 & 105 & 41.4 & 254 & 100 \\
\hline
\end{tabular}

In Table 2, when we look at the ages of the study group and their level of interest towards sports, we can see that the age group of 66 years and older were least interested in sports compared to the other age groups with $33.3 \%$ ratio, and the age group of $18-25$ were the most interested with a ratio of $77.8 \%$. The connection between the difference in age and level of interest in sports was found to be significant.

When we look at the level of interest towards sports according to the marital status of the study group in Table 3 , we can see that $77.8 \%$ of the bachelors and $58.6 \%$ of the married were interested in sports. It seems that single people are more interested in sports than married ones. The connection between the difference in marital status and level of interest in sports was found to be significant also.

Table 4. The difference in the level of education and the level of interest towards sports

\begin{tabular}{|c|c|c|c|c|c|c|}
\hline \multirow[t]{3}{*}{ Level Of Education } & \multicolumn{4}{|c|}{ Interest towards Sports } & \multicolumn{2}{|c|}{ Total } \\
\hline & \multicolumn{2}{|c|}{ Yes } & \multicolumn{2}{|c|}{ No } & \multirow[b]{2}{*}{$\mathbf{N}$} & \multirow[b]{2}{*}{$\%$} \\
\hline & $\mathbf{N}$ & $\%$ & $\mathbf{N}$ & $\%$ & & \\
\hline Literate & 14 & 42.4 & 19 & 57.6 & 33 & 100 \\
\hline Primary school & 53 & 60.9 & 34 & 39.1 & 87 & 100 \\
\hline Secondary school & 88 & 70.9 & 36 & 29.1 & 124 & 100 \\
\hline High School & 130 & 69.8 & 56 & 30.2 & 186 & 100 \\
\hline University & 124 & 73.8 & 44 & 26.2 & 168 & 100 \\
\hline Post Graduate & 10 & 83.3 & 2 & 16.7 & 12 & 100 \\
\hline
\end{tabular}

In Table 4, when we look at the level of education of the study group and the level of interest in the sports, it can be observed that the least interested are the literate group with $42.4 \%$, and the most interested are the post-graduate group with $83.3 \%$. As the educational status increases, the interest in the sports also increases. So the relation between the difference in the level of education and interest in sports was found to be significant.

In Table 5 , it can be seen that $69.8 \%$ of the study group was interested in sports and $30.2 \%$ was not.

Table 5. Interest level towards sports of the study group

\begin{tabular}{ccc}
\hline Interest towards Sports & Number & Percentage (\%) \\
\hline Yes & 426 & 69.8 \\
No & 184 & 30.2 \\
Total & 610 & 100.0 \\
\hline
\end{tabular}


Table 6. The distribution of sports branches that the study group participants are interested in

\begin{tabular}{lcc}
\hline Football & 294 & 48.2 \\
Swimming & 123 & 20.2 \\
Basketball & 59 & 9.7 \\
Volleyball & 33 & 5.4 \\
Athletics & 23 & 3.7 \\
Taekwon-do & 19 & 3.2 \\
Boxing & 14 & 2.2 \\
Ski & 11 & 1.8 \\
Gymnastics & 10 & 1.6 \\
Table tennis & 9 & 1.4 \\
Bicycle & 7 & 1.1 \\
Handball & 5 & 0.8 \\
Wrestling & 3 & 0.4 \\
Tennis & 2 & 0.3 \\
Total & 610 & 100.0 \\
\hline
\end{tabular}

Table 7. The factors that prevent the study group from participating in sports activities even when the group are interested in such sports

\begin{tabular}{lcc}
\hline Factor & Number & Percentage (\%) \\
\hline Lack of sports facilities & 158 & 25.9 \\
Intensive work tempo & 119 & 19.6 \\
No good sports facilities & 91 & 14.9 \\
Financial impossibilities & 72 & 11.9 \\
Lack of direction from sports professionals & 59 & 9.6 \\
Negative effect of environment and climate conditions & 38 & 6.3 \\
Family reasons & 29 & 4.7 \\
Lack of adequate support by local sports institutions & 27 & 4.4 \\
Traditional obstacles & 17 & 2.7 \\
\hline
\end{tabular}

In Table 6 , it can be seen that the two most popular sports branches of the study group are football with $48.2 \%$, and swimming with $20.2 \%$, and the least popular was tennis with $0.3 \%$.

In Table 7, it can be observed that the biggest factor preventing the people from participating in sports activities even when they are interested was found to be the lack of sports facilities with $25.9 \% .14 .9 \%$ participants has given the reason of not having good enough sports facilities, and $11.9 \%$ of them stated financial impossibilities, while $9.6 \%$ of them mentioned the lack of direction from professionals, $6.3 \%$ mentioned the negative environmental and climatic conditions, $4.7 \%$ of them mentioned family issues, $4.4 \%$ of them stated the lack of support from local institutions and finally, $2.7 \%$ mentioned traditional obstacles. More sports facilities are required for the people of Bingöl to actively participate in more sports activities.

According to Table 8 , it is seen that $32.2 \%$ of the study group participants state that the number of sports facilities of public institutions and organizations in Bingöl are inadequate.

Table 8. The adequacy level of sports facilities in public institutions and organizations in Bingöl, according to the study group

\begin{tabular}{lcc}
\hline Level of Adequacy & Number & Percentage (\%) \\
\hline Very adequate & 59 & 9.6 \\
Adequate & 101 & 16.6 \\
No idea & 94 & 15.5 \\
Insufficient & 197 & 32.2 \\
Very insufficient & 159 & 26.1 \\
Total & 610 & 100.0 \\
\hline
\end{tabular}


Table 9. Sports facilities in Bingöl city center

\begin{tabular}{llc}
\hline \multicolumn{1}{c}{ The Name of The } & \multicolumn{1}{c}{ Remarks } & Total \\
\hline Fym & Owned by Youth Services and Sports Provincial Directorate & 6 \\
Gym & Owned by Provincial Directorate of National Education & 6 \\
Gym & Taekwon-do, karate, body building, step and aerobic halls owned by private businesses & 5 \\
Gym & Owned by Bingöl University & 1 \\
Football field & Grass pitch (1), synthetic grass pitch football field (7) owned by Provincial Directorate of National & 8 \\
Football field & Education & Synthetic pitches owned by private businesses \\
Football field & Synthetic pitch owned by Bingöl University & 5 \\
Swimming pool & Semi-olympic pool owned by Youth Services and Sports Provincial Directorate & 1 \\
Swimming pool & Closed (3) and outdoor swimming pools (1) owned by private businesses & 1 \\
Tennis court & Owned by Youth Services and Sports Provincial Directorate & 4 \\
Tennis court & Owned by Bingöl University & 1 \\
Athletics complex & Owned by Youth Services and Sports Provincial Directorate & 1 \\
Skiing facility & Owned by Youth Services and Sports Provincial Directorate & 1 \\
\hline
\end{tabular}

Source: (Bingöl Youth Services and Sports Provincial Directorate, 2016).

\section{Discussion and Conclusion}

Increasing the number and diversity of sports facilities can be an important factor for creating a sports culture and raising awareness, and to also provide the opportunity of sports as a service to more and more people. In this comprehensive study, the data obtained from the sample group of the research in Bingöl province were tried to be evaluated in order to reveal the current situation.

When we look at the data set up in the research done, in Table 1, the interest rate of males towards sports can be seen as $68.9 \%$, while the rate for females is $64.7 \%$. Males are more interested in sports compared to females. According to Wilmore (1977), this is more likely caused by cultural and social limitations of women face after puberty, rather than physiological reasons. From this point of view, women of Bingöl should also be encouraged to participate in sport activities.

In another data set (Table 2), when we look at the ages of the study group and the level of interest in sports, it can be seen that 18-25 age group is more interested in sports with a ratio of $77.8 \%$ compared to other age groups. In a study by (Gordon, et al., 1976), it was found that withdrawal from sportive activities was increasing in later ages. The increase or decrease in the intensity of physical activity of a person is directly related to his/her age. As the age of the individual increases over 36, the level of interest towards sports also starts to decrease.

When we look at the level of interest towards sports in accordance with marital status of the study group in Table 3 , it can be seen that $77.8 \%$ of single people and $58.6 \%$ of the married people were interested in sports (Ayan, 2002), in his study, stated that while $94.3 \%$ of single respondents were interested in sports, $87.2 \%$ of married people were not interested in sports at all. From the point of view of interest towards sports, it is thought that family responsibilities and work life are influential in the evaluation of leisure time for individuals, regardless of them being single or married. For this reason, in terms of interest towards sports, it shows that single people, as they can have more free time in their hands and are away from the responsibilities of a married life, can find more time to engage in sports activities (Karataş et al., 2011)

In Table 4, when we look at the educational status of the study group and the level of interest towards sports, we can see that the level of interest towards sports increases as the level of education increases. The least interested group happened to be the literate group with $42.4 \%$, while the highest interest was shown by the post graduate group with $83.3 \%$. Similar studies by (Avşar, 1994) in Sakarya province and (Harmandar, 1994) in Uşak province shows similar results with our study. Education plays an important role on our social lives. It is certain that education will also be effective for the involvement in sports. As a person gets his/her real place in social life, his/her tendency towards sports as a social activity will also increase (Erkal, 1981). As the level of education increases, it can be said that the ideas about sports also change, and people become more aware and that the education is effective in the sparing of free time for sports for such people.

In another data table (Table 5), it was determined that $69.8 \%$ of Bingöl community are interested in sports, while $30.2 \%$ were not interested in any kind of sports at all. (Genç, 1994), in his study performed in Kayseri province, 
found that the interest level towards sports in that province is $92 \%$, and the lack of interest was $8 \%$. Thus the level of interest of Bingöl society should be increased through the organization and advertising works to be done by the Ministry of Youth and Sports or the private sector, also through the context of new policy adoption.

In Table 6 , it can be seen that $48.2 \%$ of the study group are interested in football. In similar studies, interest in football was found to be $63.4 \%$ in Samsun, $57.6 \%$ in Trabzon and $22.0 \%$ in Edirne (Harmandar, 1994). The reasons that make football so popular are its simplicity, its collectivity and fun factor for both its players and spectators. Today there is no other sports branch in Turkey or even all around the world that is as massive as football (Konter, 1996). Due to the fact that most of the existing organizations are interested in football, and because of the large-scale advertisement of it in the media, people of Bingöl also have a huge interest in football.

In Table 7 which was formed in the light of the data obtained, it can be seen that in spite of the fact that people of Bingöl are interested in sports, there are factors that prevent them from engaging in sportive activities. The biggest factor was found to be the lack of sports facilities with 25.9\%. (Ünal. 2001) in his study in Çanakkale province and (Şahin, 2007) in his study in Karaman province asked the participants why they do not engage in sports activities even though they want to. The most popular answer was the lack of facilities for popular sports branches. In our research carried out in Bingöl, it is shown that the obstacles that prevent people from engaging in sports activities is the lack of necessary facilities and also, the difficulty of finding the necessary free time from the intensive work and everyday lives of the participants in the study. The participants also mentioned that they couldn't receive good service from the existing facilities.

In Table 8 , it can be seen that according to the study group, $32.2 \%$ thinks that the sports facilities in the public establishments and institutions in Bingöl are inadequate. The inadequacy of the number of facilities in Aydın, Antalya, Muğla provinces and other cities has also been mentioned (Gökdoğan, 2007).

As a result; it was seen that the quantity and quality of sports facilities which is the most important factor for providing masses with the opportunity to engage in sports, is not enough to meet expectations. Thus new facilities to be built by the state institutions should be diversified and increased through a plan and strategy.

The individuals usually participate in sports as spectators, but they should be encouraged to actively be involved as well, by following the research activities to find out what kind of sports are the most popular and targeting these popular sports branches.

Individuals should be encouraged in order to popularize sports as a recreational activity and also as a culture, and the sportive needs of the students in educational institutions should also be met. When we consider the declining interest rate towards sports of people aged 36 and older, special programs should be broadcasted via the media and advertisements and awareness-raising activities should be carried out on the health benefits of doing sports. In today's technology world, perceptions and behavioral systematics formed after perceptions are directed through media and education. With this factor in mind, it is possible to put an effective path in encouraging people to engage in their favorite sport branches. This will not just ensure active participation of sports, but also will also increase the diversity of sport facilities.

In order to make sure that sports are socially internalized and become a part of people's lives, it is necessary to give priority to the policies regarding sports for our country and to give the necessary importance to each sports branch in terms of making and implementing these policies in accordance with the plans.

\section{References}

Avşar, B. (1994). Kitle sporunun teşviki açısından tesis politikaları Sakarya ili uygulaması. Yüksek Lisans Tezi. Marmara Üniversitesi. Sağlık Bilimleri Enstitüsü.

Ayan, S. (2002). Kırıkkale ilinde sporun yaygınlaştııllması için uygulanan spor tesis ve politikalarının incelenmesi. Yüksek Lisans Tezi. Kırıkkale Üniversitesi. Sağlık Bilimleri Enstitüsü.

Bingöl Gençlik Hizmetleri ve Spor İl Müdürlüğü. (2016). Tesisler Servisi Bölümü. Bingöl.

Devecioğlu, S. (1996). Firat havzasındaki spor teşkilatlarının sporun yaygınlaştırılmasına katkıları. Yüksek Lisans Tezi. Fırat Üniversitesi. Sağlık Bilimleri Enstitüsü.

Erkal, E. M. (1981). Sosyolojik Açıdan Spor. Filiz Kitabevi, İstanbul

Genç, V. (1994). Kitle sporu teşviki ve tesis politikası Kayseri ili uygulaması. Yüksek Lisans Tezi. Marmara Üniversitesi. Sağlık Bilimleri Enstitüsü.

Gökdoğan, D. (2007). Kahramanmaraş ilindeki öncelikli spor branşlarının tespiti ile bu branşların seçimine etki eden sebeplerin araştırılması ve kitle sporunun yaygınlaşması açısından değerlendirilmesi. Yüksek Lisans 
Tezi. Dumlupınar Üniversitesi. Sosyal Bilimler Enstitüsü.

Gordon, C. G., \& Scott, J. (1976). Leisure and Lives: Personnel Expressivity across the Life Span. In R. Bimstock, \& E. Shanas (Eds.),i Handbook of Aging and The Social Sciences.Van Nostrand Reinhold Co., New York.

Harmandar, İ. H. (1994). Kitle sporu teşviki açısından spor tesis politikası uşak ili örneği. Yüksek Lisans Tezi. Marmara Üniversitesi. Sağlık Bilimleri Enstitüsü.

Karataş, Ö., Yücel, A. S., Karademir, T., \& Karakaya, Y. E. (2011). Malatya'da Sporun Yaygınlaştırılması Açısından Spor Tesislerinin Yeterlilik Düzeyinin İncelenmesi. Hacettepe Journal of Sport Sciences, 22(4), 154-163.

Konter, E. (1996). Sporda Stres ve Performans. İzmir: Saray Medikal Yayıncılık, Başsaray Basımevi.

Şahin, M. (2007). Karaman ilindeki öncelikli spor branşlarının tespiti ile bu branşların seçimine etki eden sebeplerin araştırılması ve kitle sporunun yaygınlaşması açısından değerlendirilmesi. Yüksek Lisans Tezi, Dumlupınar Üniversitesi. Sosyal Bilimler Enstitüsü.

Ünal, B. (2001). Çanakkale ilindeki mevcut spor tesislerinin tespiti ve halkın spora yönlendirilmesi açısından değerlendirilmesi. Yüksek Lisans Tezi, Dumlupınar Üniversitesi. Sosyal Bilimler Enstitüsü.

Wilmore, J. H. (1977). Athletic Training and Physical Fitness. Allen and Bacon, Boston.

\section{Copyrights}

Copyright for this article is retained by the author(s), with first publication rights granted to the journal.

This is an open-access article distributed under the terms and conditions of the Creative Commons Attribution license (http://creativecommons.org/licenses/by/4.0/). 